\title{
THE ROLE OF NEW TECHNOLOGIES IN DEFINING SALIVARY PROTEIN COMPOSITION FOLLOWING PLACEMENT OF FIXED ORTHODONTIC APPLIANCES - BREAKTHROUGH IN THE DEVELOPMENT OF NOVEL DIAGNOSTIC AND THERAPEUTIC PROCEDURES
}

\author{
Vojka Zgombić Popović ${ }^{1}$, Lovorka Grgureviće,4, Vladimir Trkulja ${ }^{3}$, \\ Ruđer Novak ${ }^{4}$ and Dubravka Negovetić-Vranićs
}

\author{
${ }^{1}$ Orthonova Dental Polyclinic, Zagreb, Croatia; \\ ${ }^{2}$ Drago Perović Department of Anatomy, School of Medicine, University of Zagreb, Zagreb, Croatia; \\ ${ }^{3}$ Department of Pharmacology, School of Medicine, University of Zagreb, Zagreb, Croatia; \\ ${ }^{4}$ Center for Translational and Clinical Research, Department of Proteomics, \\ School of Medicine, University of Zagreb, Zagreb, Croatia; \\ ${ }^{5}$ Department of Pediatric and Preventive Dentistry, School of Dental Medicine, \\ University of Zagreb, Zagreb, Croatia
}

\begin{abstract}
SUMMARY - Human saliva is rich in proteins of variable functions (e.g., enzymes, immunoglobulins, cytokines) and origin (blood plasma, salivary glands, or oral microflora). Circadian dynamics, volume and composition (electrolytes, $\mathrm{pH}$, protein, etc.) of secreted saliva vary with local and systemic physiological and pathophysiological conditions. Therefore, the composition of saliva, protein in particular, has been intensively investigated to identify the potential markers and/or mechanisms of systemic and local diseases. Proteomic techniques used for the analysis of biological fluids have enabled great advances in salivary protein stabilization (as the main precondition for their analysis) and detection of those found in saliva in very low concentrations, including small proteins and peptides. This review brings the main characteristics of current proteomic techniques such as liquid chromatography-mass spectrometry, two-dimensional electrophoresis-mass spectrometry, and surfaceenhanced laser desorption ionization/time of flight/mass spectrometry. These techniques enable simultaneous identification of hundreds and thousands of protein molecules, as well as identifying those of a potential biological value in particular states. This literature review is focused on the state-of-the-art and possibilities offered by proteomic techniques in analyzing the effects of orthodontic appliances on salivary protein composition and searching for potential markers of therapeutic success/failure or for the molecules by which therapeutic effects are achieved.
\end{abstract}

Key words: Saliva; Proteomics; Orthodontic appliance; Salivary protein

\section{Introduction}

Oral cavity is the initial segment of the digestive system, which includes a number of structural elements relevant for correct body functioning. Saliva is a biological fluid found in oral cavity; it is clear, slightly
Correspondence to: Prof. Lovorka Grgurević, PhD, Drago Perović Department of Anatomy and Center for Translational and Clinical Research, Department of Proteomics, School of Medicine, University of Zagreb, Šalata 11, HR-10000 Zagreb Croatia E-mail: lgrgurev@mef.hr

Received January 23, 2019, accepted April 20, 2019 
acidic fluid ( $\mathrm{pH}$ 6.0-7.0) composed of a mixture of salivary gland secretions (parotid, submandibular and sublingual glands), secretions of numerous small oral mucosa glands, and gingival fluid. Saliva closely resembles blood by composition; as a complex fluid, it contains a large number of enzymes, hormones, antibodies, cytokines and antimicrobial substances ${ }^{1}$. Saliva is blood plasma ultrafiltrate because numerous molecules pass from blood to saliva via gingival sulcus and salivary glands, crossing the cells or paracellularly via extracellular ultrafiltration ${ }^{2}$. Saliva exerts high antimicrobial effect with the well-known salivary electrolytes and enzymes playing the bactericidal role. Mention should be made of immunoglobulin A (IgA), the main function of which is preventing microorganism adherence to mucosal surface receptors. In case of reduced salivation, the mechanisms of oral cavity defense are impaired due to modified composition of antimicrobial factors ${ }^{3,4}$.

Alterations in the physiologic state of the body including emotional, endocrine, nutritional and metabolic changes can also be observed in saliva. That is why saliva is considered a potential source of data for assessment of health state, not only of oral cavity but also of the whole body. Saliva is a very useful diagnostic sample because it is easy to obtain noninvasively, is very similar to blood, and salivary sample is less complex $^{5}$; however, saliva is subject to many influences that should be defined prior to any analysis. Many molecules currently considered as biomarkers are known to be liable to changes in their qualitative and quantitative composition throughout the day (circadian rhythm); they can depend on sex, age and numerous physiological processes such as pregnancy, exercise and physical activity, cigarette smoking, and stress ${ }^{6,7}$. Similar variations in the occurrence and concentration of particular enzymes have also been observed in saliva as a biological fluid ${ }^{8,9}$, calling for caution on interpreting results on the expression of the potential biomarkers of pathophysiological states.

In the past two decades, a number of concepts defining saliva as a diagnostic material in the follow up of oral diseases such as periodontal diseases and an increased risk of caries development have been developed $^{10-12}$. A great number of medically valuable salivary parameters have been used as potential biomarkers in the assessment of numerous pathologic conditions such as tumor diseases ${ }^{13}$, cardiovascular disease ${ }^{14}$, bacterial and viral infections ${ }^{15,16}$, and autoimmune disorders ${ }^{17}$. The advent of new technologies has also modified saliva definition as a prognostic and diagnostic biological material. Previous technologies could only identify common molecules, whereas less common ones that previously could not be detected frequently are much more relevant for assessment of a particular (patho)physiological state ${ }^{18}$. Recent studies of human saliva proteome determination show that besides the main plasma proteins including alpha amylase, saliva also contains hundreds of small molecules or peptides that define the basis for development of the potential health and disease biomarkers ${ }^{19}$. For example, salivary proteome that includes protein classification according to the salivary gland producing them has been detected by use of proteomic methods, i.e. high-sensitive mass spectrometry in combination with various separation methods ${ }^{20-22}$. Human plasma proteome is one of the most extensively investigated groups of human proteins, through collaboration of many laboratories employing mass spectrometry including the Human Plasma Proteome Project ( $\mathrm{Hu}-$ man Proteome Organization, HUPO). Comparison of salivary protein composition with plasma proteins revealed $27 \%$ of total salivary proteins to be found in plasma as well ${ }^{23}$. Although at seemingly a relatively low percentage, analysis of gene ontology such as molecular function, cellular compartment and biologic activity showed high overlap of functional protein groups between these two specimens ${ }^{24}$. This article provides a review of studies investigating the impact of orthodontic appliances on salivary protein composition to define the unknowns, while expecting additional research to bring novel concepts on the effect of these appliances on protein expression, along with developing new guidelines for their utilization.

\section{The Impact of Orthodontic Appliances on Salivary Composition}

The teeth undergo physiologic movements on their adjustment in dental alveolus during growth and development of head bones (including maxilla and mandible) and other related anatomic structures. Irregular bite results in disproportionate size of the teeth and jaws. Teeth become packed, occasionally requiring placement of an orthodontic appliance to move the teeth by mechanical force (orthodontic movements). 
The impact of orthodontic treatment on microbiological salivary composition at particular time intervals has been confirmed in many studies ${ }^{25}$. The quality of saliva including protein composition, viscosity, $\mathrm{pH}$ value, buffer capacity, and specific salivation within a time interval play a key role in the tooth enamel demineralization to remineralization ratio in a cariogenic milieu. Any orthodontic procedure may influence the mentioned components; therefore, the aim of some prospective studies was to demonstrate the effect of fixed orthodontic appliances on salivary $\mathrm{pH}$, buffer capacity and salivation rate at defined time points. These studies did not find a statistically significant difference in those parameters between baseline values and those recorded at one year ${ }^{26,27}$. However, other studies showed significant increase in stimulated salivation (in response to foreign body placement in oral cavity), salivary $\mathrm{pH}$ and buffer capacity ${ }^{28-31}$. In addition, the number of bacteria of the genus Lactobacillus was found to have increased. The increase in these parameters was recorded shortly after placement of the appliance, as a response to mechanical irritation, suggesting that their modification might have protective action against caries development. Long-standing use of orthodontic appliances may influence the occurrence of caries; therefore, attention should be focused on oral cavity hygiene and dietary habits.

The saliva of patients undergoing orthodontic treatment with fixed appliances may be less efficient in recovering $\mathrm{pH}$ value following acidic drink intake as compared with subjects without such appliances, i.e. patients with fixed orthodontic appliances are at a higher risk of dental lesions ${ }^{32}$. The more so, $\mathrm{pH}$ value was found to have decreased following placement of orthodontic appliance ${ }^{33}$, leading to greater dental plaque deposits and higher bacterial colonization of tooth surface, manifested by white spots on tooth enamel $^{34}$ and demineralization ${ }^{35}$. Results of studies investigating the effect of orthodontic appliances on the composition of oral microbiological flora are quite controversial. An in vivo study including twenty children aged 6-15 years showed a significant increase of Streptococcus mutans and Lactobacillus sp. bacteria, as well as Candida albicans fungus at various intervals following placement of the appliances ${ }^{36,37}$, whereas a study in 32 patients with various types of orthodontic appliances recorded no increase in Streptococcus mutans and Streptococcus sobrinus colonies as compared with control group ${ }^{38}$. A study that included 54 adult patients with fixed appliances reported increase in the Aggregatibacter actinomycetemcomitans and Fusobacterium nucleatum bacteria following appliance removal, pointing to the risk of developing periodontal disease, as well as to the need of better oral hygiene during and after appliance utilization ${ }^{39}$. Ahn et al. compared salivary amino acid composition before and after placing orthodontic brackets made of various materials and found major changes in the salivary amino acid composition that reflected on the salivary qualitative protein composition. Upon placement of plastic brackets, the concentration of proteins containing the amino acid proline increased, which is a factor favoring the Streptococcus gordonii bacterium colonization of the brackets and tooth enamel ${ }^{34}$. Low molecular mass proteins rich in proline, alpha amylase and mucine favor Streptococcus gordonii adhesion and caries development. Depending on their amino acid composition, selective protein binding to orthodontic brackets creates a milieu favoring bacterial growth, differentiating the brackets from other materials such as those used for fillings and tooth enamel ${ }^{40}$.

Analysis of oxidative stress markers and antioxidative response in healthy individuals with fixed orthodontic appliances revealed modifications in their balance, associated with nickel release from the orthodontic appliance to the saliva ${ }^{34,35,41-45}$. The release of nickel and other metals induces inflammatory reaction, and even systemic allergic reactions in individuals with hypersentivity ${ }^{43,46}$. An intriguing study investigated mobile phone usage, nickel release and salivary $\mathrm{pH}$ in 42 healthy subjects wearing orthodontic appliances. Mobile phone electromagnetic radiation causes significant increase in oxidative stress and salivation, which can have corrosive effect on the appliance metal component. Study results revealed higher nickel release and lower salivary $\mathrm{pH}$ in mobile phone users as compared with those that did not use mobile phones ${ }^{47}$. In addition, the amount of nickel released from fixed orthodontic appliances was found to significantly influence salivary $\mathrm{pH}^{48}$. Experiments in animals and humans confirmed that mobile phone radiation caused increase in salivary oxidative stress and total protein and albumin pulmonary flow, and decrease in amylase activity ${ }^{49}$. Adverse effects of mobile phone usage generally are induced by emission of radiofrequency electromagnetic radiation ${ }^{50}$. As mobile phone is held adja- 
cently to oral cavity while talking, the patients undergoing fixed orthodontic procedure may be at a high risk of their metal appliance exposure to mobile phone radiation, which leads to the release of toxic corrosive products in saliva.

The placement of orthodontic appliance provokes inflammatory reaction known as sterile inflammation, which in turn may result in gingivitis and other pathologic conditions in oral cavity ${ }^{51,52}$. In some studies, changes in inflammatory parameters such as $\mathrm{C}$-reactive protein, as well as concentrations of albumin and other plasma proteins known to rise in inflammation were observed, however, their increase in saliva upon placement of orthodontic appliance could not be confirmed with certainty. Orthodontic treatment is also associated with dental root resorption; it is very low in most patients but may be moderate to severe in some patients. Analysis of inflammatory cytokine expression in the groups with moderate and severe absorption revealed their salivary concentrations of interleukin (IL)-7, IL-10, IL-12p70 and interferon- $\gamma$ to be significantly increased, along with IL-4 decrease as compared to control group ${ }^{53}$. In this scenario, patient saliva proved to be a readily available and valuable analytical sample, which showed correlation of the cytokine values measured in comparison to blood sample. Saliva as a biological fluid was also used in studies assessing the effect of fixed and removable appliances on the amylase and lysozyme enzyme activities in the saliva of children aged 7-18 years. At six months of wearing orthodontic appliances, a decrease in amylase activity was recorded in both groups (fixed and removable appliances), whereas lysozyme activity was lower in the group with fixed appliances ${ }^{54}$. These changes point to the effect of these enzymes and the level of their expression on the development of complications such as caries, gingivitis and periodontitis.

The placement of orthodontic appliances results in tooth movements including all elements of bone rearrangement, i.e. bone formation and degradation, which overlap in the second week of appliance placement. On applying orthodontic force upon the tooth, the surrounding tissue responds to mechanical stress with inflammatory reaction and cell necrosis, which in turn leads to the release of many enzymes such as lactate dehydrogenase and aspartate aminotransferase (AST) into saliva and gingival cervical fluid ${ }^{51}$. AST levels rise in the first week, reflecting the process of bone forma- tion, followed by the process of bone resorption accompanied by increased activity of tartrate-resistant acid phosphatase in the second week of appliance placement. The activity of alkaline phosphatase, a marker of increased bone mineralization, also is on an increase from week 1 to week 5 of appliance placement. The values of these enzymes in saliva can serve for follow up of orthodontic tooth movement in dental alveolus ${ }^{55,56}$. The enzyme myeloperoxidase (MPO), found in polymorphonuclear granulocytes, can serve as an indirect indicator of inflammatory reaction in periodontal tissue. MPO concentration measured in the saliva and cervical fluid of patients undergoing orthodontic treatment did not indicate significant correlation between mechanical force exerted upon the brackets and enzyme activity ${ }^{25}$.

\section{Proteomic Methods in Saliva Analysis}

Saliva is a biological fluid with a great basic and clinical potential; in proteomics, saliva is generally used to differentiate physiological and pathophysiological conditions (Fig. 1). Analysis of salivary proteome in many pathophysiological conditions has recently suggested a number of biomarkers that need to be validated in clinical practice. The expected indications for which salivary proteins have been investigated as biomarkers include inflammatory diseases of the digestive system, such as periodontitis ${ }^{57}$, gingivitis ${ }^{58}$ and inflammatory bowel disease ${ }^{59}$. Salivary proteome analysis has an ever greater and relevant role in early identification of many cancer types such as oral cancer $^{60,61}$, gastric cancer ${ }^{62}$ and lung cancer ${ }^{63}$. In addition, these investigations are of utmost importance for attempts to identify biomarkers of autoimmune disorders such as Sjögren's syndrome ${ }^{64}$ and systemic lupus erythematosus ${ }^{65}$. Finally, owing to noninvasive and easy collection of salivary samples, identifying disease biomarkers in saliva is of utmost importance for patients with neurological, psychiatric and neuroendocrine disorders such as autism ${ }^{66}$, schizophrenia and bipolar disorder ${ }^{67}$, and Parkinson's disease ${ }^{68}$.

Besides its high diagnostic and prognostic potential, noninvasive and easy sampling and minimal cost make saliva an ideal substitution for blood, serum and plasma. Verification of the hypothesis that human saliva reflects the entire body condition would be of great value, in which crucial is defining appropriate proce- 


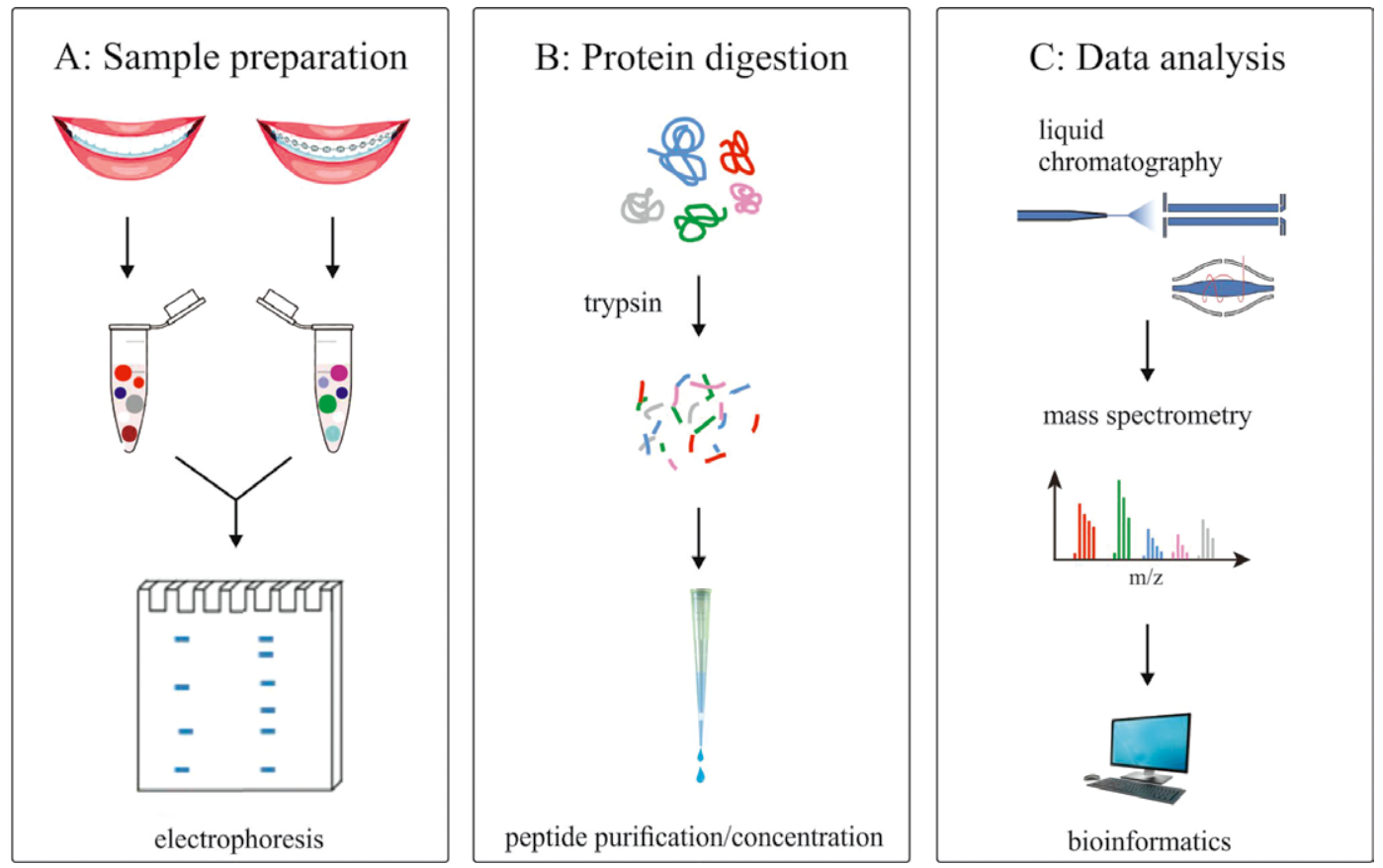

Fig. 1. Quantitative saliva proteomics workflow: $(A)$ saliva samples are collected and proteins denatured and separated by gel electrophoresis; (B) proteins of interest are extracted from the gel and digested using a peptidase (usually trypsin); the peptides obtained are further purified and concentrated using a C18 chromatographic column; (C) after separation by liquid chromatography, peptides are sequenced by mass spectrometry and bioinformatics tools are applied to extract biologically relevant information.

dures of correct sample preparation for analysis and employing current technologies in detection and quantification of the main salivary components. With the use of modern instruments and development of analytical technologies, proteomics has imposed as a potent approach in detecting biomarkers in saliva. Currently there is no proteomic protocol for analysis of the whole saliva proteome; however, two different experimental approaches have appeared. The topdown approach analyzes native proteins or peptides in saliva, whereas in the bottom-up approach proteins are enzymatically broken down to peptides prior to analysis (identification). The key component of proteomic analysis is achieving salivary proteome stability by correct sample manipulation, preparation and storage until analysis. Salivary proteome is subject to fast degradation by endogenous peptidases from saliva, which can compromise and prevent its use in clinical diagnosis. The activity of proteolytic enzymes results in fast protein degradation, which is prevented by use of protease inhibitors on salivary sample preparation for analysis. Unfortunately, these inhibitor cocktails cannot completely prevent protein degradation; therefore, efforts are made to upgrade the proteome stabilization technology by use of glycerol and ethanol. By using ethanol, sample stabilization at room temperature for up to two weeks can be achieved ${ }^{69}$.

Some researchers employed two-dimensional gel electrophoresis (2-DE) for separating salivary protein molecules; after protein digestion from the gel, samples were analyzed by mass spectrometry (2D-MS). Using this approach, 19 proteins specific for saliva and 18 serum proteins were identified ${ }^{70,71}$. Although 2DMS has great potential, problem arises on identifying low molecular mass proteins, high-acidic or alkaline proteins, hydrophilic proteins, or those found in very small amounts. Alternative to it is liquid chromatography as a separation step prior to mass spectrometry (LC-MS). Employing this technology, 102 salivary proteins and 67 serum proteins were identified; however, using this technology little information is obtained on protein representation in saliva. A combina- 
tion of LC-MS and 2D-MS technologies yielded highest increase in the number of proteins identified, 309 in total. Employing the latest preparative chromographic separation techniques coupled with modern mass spectrometers has recently resulted in identification of more than 5500 proteins in human saliva, many of them originating from oral microflora that consists of more than 50 bacterial genera ${ }^{72}$. The surface-enhanced laser desorption/ionization/time-of-flight/ mass spectrometry (SELDI-TOF-MS) technology is also used in saliva analysis to analyze whole saliva proteomic composition. This technology requires small sample volume while offering fast analysis of various chromatographic spectra, thus enabling subsequent optimal purification of the proteins of interest ${ }^{73}$. This technology was employed in analyzing salivary proteome profile in patients with orthodontic treatment at baseline and at three months of appliance placement. Study results showed difference in proteome profile between two measurements, with overt difference in protein expression at three months of wearing orthodontic appliances ${ }^{74}$. As protein analysis enables simultaneous searching for/identification of hundreds or even thousands of various protein molecules, proteome methods can be used to study particular cellular process in 'opposite direction', i.e. instead of targeted searching for the molecule of interest, proteomics enables designing a proteomic profile of a particular sample and identification of potential biologically relevant molecules.

\section{Conclusion}

The effect of orthodontic appliances on the protein composition of saliva has not yet been fully elucidated, although there are interesting results in the field indicating that determination of specific protein molecules in saliva may play a major role in differentiating healthy from pathologic state in oral cavity. These results might stimulate designing additional research to test the effects of new drugs or diagnostic procedures by analyzing salivary protein composition, not only in diagnosis and follow up of pathologic lesions in oral cavity but also systemically. Determination of salivary proteomic profile before, during and after therapeutic procedure can provide valuable information on the effect of a drug or therapeutic procedure. Additional studies and upgrading the methods of saliva analysis as a biological fluid pose a great challenge indeed.

\section{References}

1. Rehak NN, Cecco SA, Csako G. Biochemical composition and electrolyte balance of "unstimulated" whole human saliva. Clin Chem Lab Med. 2000;38:335-43, https://doi.org/10.1515/ CCLM.2000.049

2. Drobitch RK, Svensson CK. Therapeutic drug monitoring in saliva. An update. Clin Pharmacokinet. 1992;23(5):365-79, https://doi.org/10.2165/00003088-199223050-00003

3. Cekić-Arambašin A, Vidas I, Topić B, Alajbeg I, Vučićević Boras V, Biočina-Lukenda D, Glažar I, Maričić D. Oralna medicina. Zagreb: Školska knjiga, 2005; p. 29-195. (in Croatian)

4. Guyton AC. Fiziologija čovjeka i mehanizmi bolesti - sekrecijske funkcije probavnog sustava. $5^{\text {th }}$ edn. Zagreb: Medicinska naklada, 1995; p. 465-76. (in Croatian)

5. Hirtz C, Vialaret C, Nowak N, Gabelle A, Deville de Periere D, Lehmann S. Absolute quantification of 35 plasma biomarkers in human saliva using targeted MS. Bioanalysis. 2016; 8(1):43-53, https://doi.org/10.4155/bio.15.228

6. Murr A, Pink C, Hammer E, Michalik S, Dhople VM, Holtfreter B, Völker U, Kocher T, Gesell Salazar M. Cross-sectional association of salivary proteins with age, sex, body mass index, smoking, and education. J Proteome Res. 2017;16(6):2273-81. doi: 10.1021/acs.jproteome.7b00133

7. Marvin RK, Saepoo MB, Ye S, White DB, Liu R, Hensley K, Rega P, Kazan V, Giovannucci DR, Isailovic D. Salivary protein changes in response to acute stress in medical residents performing advanced clinical simulations: a pilot proteomics study. Biomarkers. 2017;22(3-4):372-82. doi: 10.1080/1354 750X.2017.1279215

8. Tecles F, Tvarijonaviciuate A, De Torre C, Carrillo JM, Rubio M, Garcia M, Cugat R, Ceron JJ. Total esterase activity in human saliva: validation of an automated assay, characterization and behavior after physical stress. Scand J Clin Lab Invest. 2016;76(4):324-30. doi: 10.3109/00365513.2016.1163417

9. Wang X, Kaczor-Urbanowicz KE, Wong DT. Salivary biomarkers in cancer detection. Med Oncol. 2017;34(1):7, https:// dx.doi.org/10.1007\%2Fs12032-016-0863-4

10. Kornman KS, Crane A, Wang HY. The interleukin-1 genotype as a severity factor in adult periodontal disease. J Clin Periodontol. 1997;24:72-7, https://doi.org/10.1111/j.1600-051x. 1997.tb01187.x

11. Baughan LW, Robertello FJ, Sarrett DC, Denny PA, Denny PC. Salivary mucin is related to oral Streptococcus mutans in elderly people. Oral Microbiol Immunol. 2000;15:10-4, https:// doi.org/10.1034/j.1399-302x.2000.150102.x

12. Haigh BJ, Stewart KW, Whelan JR, Barnett MP, Smolenski GA, Wheeler TT. Alterations in the salivary proteome associated with periodontitis. J Clin Periodontol. 2010;37(3):241-7, https://doi.org/10.1111/j.1600-051x.2009.01525.x 
13. Zhang L, Farrell JJ, Zhou H. Salivary transcriptomic biomarkers for detection of resectable pancreatic cancer. Gastroenterology. 2010;138:949-57, https://dx.doi.org/10.1053\%2Fj.gastro.2009.11.010

14. Adam DJ, Milne AA, Evans SM. Serum amylase isoenzymes in patients undergoing operation for ruptured and non-ruptured abdominal aortic aneurysm. J Vasc Surg. 1999;30:229-35, https://doi.org/10.1016/s0741-5214(99)70132-1

15. Lendenmann U, Grogan J, Oppenheim FG. Saliva and dental pellicle - a review. Adv Dent Res. 2000;14:22-8. doi: 10.1177 /08959374000140010301

16. Emmons W. Accuracy of oral specimen testing for human immunodeficiency virus. Am J Med. 1997;102:15-20, https://doi. org/10.1016/s0002-9343(97)00033-8

17. Hu S, Wang J, Meijer J. Salivary proteomic and genomic biomarkers for primary Sjögren's syndrome. Arthritis Rheum. 2007;56:3588-600, https://doi.org/10.1002/art.22954

18. Helmerhorst EJ, Oppenheim FG. Saliva: a dynamic proteome. J Dent Res. 2007;86:680-93, https://doi.org/10.1177/1544 05910708600802

19. Spielmann N, Wong DT. Saliva: diagnostics and therapeutic perspectives. Oral Dis. 2011;17:345-54, https://doi.org/10. 1111/j.1601-0825.2010.01773.x

20. Lee YH, Wong DT. Saliva: an emerging biofluid for early detection of diseases. Am J Dent. 2009;22(4):241-8.

21. Guo T, Rudnick PA, Wang W, Lee CS, Devoe DL, Balgley BM. Characterization of the human salivary proteome by capillary isoelectric focusing/nanoreversed-phase liquid chromatography coupled with ESI-tandem MS. J Proteome Res. 2006;5:1469-78. https://doi.org/10.1021/pr060065m

22. Hu S, Loo JA, Wong DT. Human saliva proteome analysis. Ann N Y Acad Sci. 2007;1098:323-9, https://doi.org/10.1196/ annals.1384.015

23. Yan W, Apweiler R, Balgley BM. Systematic comparison of the human saliva and plasma proteomes. Proteomics Clin Appl. 2009;3:116-34, https://doi.org/10.1002/prca.200800140

24. Loo JA, Yan W, Ramachandran P, Wong DT. Comparative human salivary and plasma proteomes. J Dent Res. 2010;89(10): 1016-23, https://dx.doi.org/10.1177\%2F0022034510380414

25. Navaro-Palacios A, Garcia-Lopez E, Meza-Rios A, Armendariz-Borunda J, Sandoval-Rodriguez A. Myeloperoxidase enzymatic activity is increased in patients with different levels of dental crowding after initial orthodontic activation. Am J Orthod Dentofacial Orthop. 2014;146:92-7, https://doi. org/10.1016/j.ajodo.2014.04.015

26. Bonetti GA, Incerti Parenti S, Garulli G, Gatto MR, Checchi L. Effect of fixed orthodontic appliances on salivary properties. Prog Orthod. 2013;18(14):13. doi: 10.1186/2196-1042-14-13

27. Sanpei S, Endo T, Shimooka S. Caries risk factors in children under treatment with sectional brackets. Angle Orthod. 2010; 80:509-14. doi: 10.2319/072909-431.1

28. Chang HS, Walsh LJ, Freer TJ. The effect of orthodontic treatment on salivary flow, $\mathrm{pH}$, buffer capacity, and levels of mutans streptococci and lactobacilli. Aust Orthod J. 1999;15:229-34.
29. Lara-Carrillo E, Montiel-Bastida NM, Sánchez-Pérez L, Alanís-Tavira J. Effect of orthodontic treatment on saliva, plaque and the levels of Streptococcus mutans and Lactobacillus. Med Oral Patol Oral Cir Bucal. 2010;15(6):e924-9. doi: 10.4317/ medoral.15.e924

30. Peros K, Mestrovic S, Anic-Milosevic S, Slaj M. Salivary microbial and nonmicrobial parameters in children with fixed orthodontic appliances. Angle Orthod. 2011;81(5):901-6. doi: 10.2319/012111-44.1

31. Vanishree T, Panchmal GS, Shenoy R, Jodalli P, Sonde L, Kundapur N. Changes in the oral environment after placement of fixed orthodontic appliance for the treatment of malocclusion - a descriptive longitudinal study. Oral Health Prev Dent. 2017;15(5):453-9. doi: 10.3290/j.ohpd.a38776

32. Turssi CP, Silva CS, Bridi EC, Amaral FL, Franca FM, Basting RT. Kinetics of salivary $\mathrm{pH}$ after acidic beverage intake by patients undergoing orthodontic treatment. Gen Dent. 2015; 63(3):26-30

33. Zogakis IP, Koren E, Gorelik S, Ginsburg I, Shalish M. Effect of fixed orthodontic appliances on nonmicrobial salivary parameters. Angle Orthod. 2018;88:6:806-11, https://doi.org/ 10.2319/111317-773.1

34. Ahn SJ, Kho HS, Lee SW, Nahm DS. Roles of salivary proteins in the adherence of oral streptococci to various orthodontic brackets. J Dent Res. 2002;81(6):411-5, https://doi.org/ 10.1177/154405910208100611

35. Ahn SJ, Kho HS, Kim KK, Nahm DS. Adhesion of oral streptococci to experimental bracket pellicles from glandular saliva. Am J Orthod Dentofacial Orthop. 2003;124(2):198-205, https://doi.org/10.1016/S0889-5406(03)00346-9

36. Kundu R, Tripathi AM, Jaiswal JN, Ghoshal U, Palit M, Khanduja S. Effect of fixed space maintainers and removable appliances on oral microflora in children: an in vivo study. J Indian Soc Pedod Prev Dent. 2016;34(1):3-9. doi: 10.4103/09704388.175498

37. Stefano M, Nota A, Caruso S, Quinzi V, Marchetti E, Marzo G. Salivary markers and microbial flora in mouth breathing late adolescents. Hindawi BioMed Res Int. 2018;8:8687608. doi: 10.1155/2018/8687608

38. Jurela A, Repic D, Pejda S, Juric H, Vidakovic R, Matic I, Bosnjak $A$. The effect of two different bracket types on the salivary levels of $S$. mutans and $S$. sobrinus in the early phase of orthodontic treatment. Angle Orthod. 2013;83(1):140-5. doi: 10.2319/030612-187.1

39. Kim K, Jung WS, Cho S, Ahn SJ. Changes in salivary periodontal pathogens after orthodontic treatment: an in vivo prospective study. Angle Orthod. 2016;86(6):998-1003. doi: 10.2319/070615-450.1

40. Lee SJ, Kho HS, Lee SW, Yang WS. Experimental salivary pellicles on the surface of orthodontic materials. Am J Orthod Dentofacial Orthop. 2001;119(1):59-66, https://doi.org/ 10.1067/mod.2001.110583

41. Buczko P, Szarmach I, Grycz M, Kasacka I. Caspase-3 as an important factor in the early cytotoxic effect of nickel on oral mu- 
cosa cells in patients treated orthodontically. Folia Histochem Cytobiol. 2017;55(1):37-42. doi: 10.5603/FHC.a2017.0004

42. Lages RB, Bridi EC, Perez CA, Basting RT. Salivary level of nickel chromium, iron, and copper in patients treated with metal or aesthetic fixed orthodontic appliances: retrospective cohort study. J Trace Elem Med Biol. 2017;40:67-71, https:// doi.org/10.1016/j.jtemb.2016.12.011

43. Sahoo EN, Kailasam V, Padmanabham S, Chitharanjan AB. In vivo evaluation of salivary nickel and chromium levels in conventional and self-ligating brackets. Am J Orthod Dentofacial Orthop. 2011;140(3):340-5, https://doi.org/10.1016/j.ajodo.2010.05.022

44. Talic NF, Alnahwi HH, Al-Faraj AS. Nickel and chromium levels in the saliva of a Saudi sample treated with fixed orthodontic appliances. Saudi Dent J. 2013;25(4):129-33, https:// doi.org/10.1016/j.sdentj.2013.10.001

45. Nayak RS, Khanna B, Pasha A, Vinay K, Narayan A, Chaitra K. Evaluation of nickel and chromium iron release during fixed orthodontic treatment using inductively coupled plasma-mass spectrometer: an in vivo study. J Int Oral Health. 2015;7(8): 14-20.

46. Bhasin V, Pustake SJ, Joshi V, Tiwari A, Bhasin M, Punia RS. Assessment of changes in nickel and chromium levels in the gingival cervicular fluid during fixed orthodontic treatment. J Contemp Dent Pract. 2017;18(8):675-8, https://doi.org/ 10.5005/jp-journals-10024-2105

47. Nanjannawar LG, Girme TS, Agrawal JM, Agrawal MS, Fulari SG, Shetti SS, Kagi VA. Effect of mobile phone usage on nickel ions release and $\mathrm{pH}$ of saliva in patients undergoing fixed orthodontic treatment. J Clin Diagn Res. 2017;11(9):ZC84ZC87. doi: 10.7860/JCDR/2017/27800.10679

48. Sheibaninia A. Effect of thermocycling of nickel release from orthodontic arch wires: an in vitro study. Biol Trace Elem Res. 2014;162(1-3):353-9, http://dx.doi.org/10.1007/s12011-015$0362-z$

49. Hamzany Y, Feinmesser R, Shpitzer T, Mizrachi A, Hilly O, Hod R. Is human saliva an indicator of the adverse health effects of using mobile phones? Antioxid Redox Signal. 2013; 18:622-7, https://doi.org/10.1089/ars.2012.4751

50. Ionescu I-C, Ionescu E. Orthodontic archwires and brackets may interact with mobile phones in close proximity. Proc Rom Acad Series B. 2012;2:135-42.

51. Wahab ARM, Kasim NA, Senafi S, Jemain AA, Zainol Abidin IZ, Shahidan MA. Enzyme activity profiles and ELISA analysis of biomarkers from human saliva and gingival cervicular fluid during orthodontic tooth movement using self-ligating brackets. Oral Health Dental Manag. 2014;13(2):194-9.

52. Melsen B. Tissue reaction to orthodontic tooth movement - a new paradigm. Eur J Orthod. 2001;23(6):671-81. doi: 10.1093/ ejo/23.6.671

53. Yashin D, Dalci O, Almuzian M, Chiu J, Ahuja R, Goel A, Darendeliler MA. Markers in blood and saliva for prediction of orthodontically induced inflammatory root resorption: a retro- spective case controlled-study. Progress Orthod. 2017;18:27. doi: 10.1186/s40510-017-0176-y

54. Пачевська АВ, Білошицька АВ. Markers of dental children's health in the application of therapeutic orthodontic equipment. Wiad Lek. 2017;70(3 pt 1):489-92. (in Ukrainian)

55. Wahab ARM, Dasor MM, Senafi S, Abdullah AAA, Yamamoto Z, Jemain AZ, Ariffin SHZ. Crevicular alkaline phosphatase activity and rate of tooth movement of female orthodontic subjects under different continuous force applications. Hindawi Publishing Corporation. Int J Dentistry. 2013;Article ID 245818, https://doi.org/10.1155/2013/245818

56. Perinetti G, Paolantonio M, D'Attilio M, D'Archivio D, Tripodi D, Femminella B, Festa F, Spoto G. Alkaline phosphatase activity in gingival crevicular fluid during human orthodontic tooth movement. Am J Orthod Dentofacial Orthop. 2002; 122(5):548-56. doi: 10.1067/mod.2002.126154

57. Bostanci N, Bao K. Contribution of proteomics to our understanding of periodontal inflammation. Proteomics. 2017;17:34. doi: $10.1002 /$ pmic. 201500518

58. Aboodi GM, Sima C, Moffa EB, Crosara KT, Xiao Y, Siqueira WL, Glogauer M. Salivary cytoprotective proteins in inflammation and resolution during experimental gingivitis - a pilot study. Front Cell Infect Microbiol. 2016;5:92. doi: 10.3389/ fcimb.2015.00092

59. Zheng X, Chen F, Zhang Q, Liu Y, You P, Sun S, Lin J, Chen N. Salivary exosomal PSMA7: a promising biomarker of inflammatory bowel disease. Protein Cell. 2017;8(9):686-95. doi: 10.1007/s13238-017-0413-7

60. Kawahara R, Bollinger JG, Rivera C, Ribeiro AC, Brandão TB, Paes Leme AF, MacCoss MJ. A targeted proteomic strategy for the measurement of oral cancer candidate biomarkers in human saliva. Proteomics. 2016;16(1):159-73. doi: 10.1002/ pmic.201500224

61. Sivadasan P, Gupta MK, Sathe GJ, Balakrishnan L, Palit P, Gowda H, Suresh A, Kuriakose MA, Sirdeshmukh R. Human salivary proteome - a resource of potential biomarkers for oral cancer. J Proteomics. 2015;127(Pt A):89-95. doi: 10.1016/j. jprot.2015.05.039

62. Xiao H, Zhang Y, Kim Y, Kim S, Kim JJ, Kim KM, Yoshizawa J, Fan LY, Cao CX, Wong DT. Differential proteomic analysis of human saliva using tandem mass tags, quantification for gastric cancer detection. Sci Rep. 2016;6:22165. doi: 10.1038/ srep22165

63. Sun Y, Huo C, Qiao Z, Shang Z, Uzzaman A, Liu S, Jiang X, Fan LY, Ji L, Guan X, Cao CX, Xiao H. Comparative proteomic analysis of exosomes and microvesicles in human saliva for lung cancer. J Proteome Res. 2018;17(3):1101-7, https:// doi.org/10.1021/acs.jproteome.7b00770

64. Aqrawi LA, Galtung HK, Vestad B, Øvstebø R, Thiede B, Rusthen S, Young A, Guerreiro EM, Utheim TP, Chen X. Identification of potential saliva and tear biomarkers in primary Sjögren's syndrome, utilising the extraction of extracellular vesicles and proteomics analysis. Utheim Arthritis Res Ther. 2017;19(1):14. doi: 10.1186/s13075-017-1228-x 
65. Abrão AL, Falcao DP, de Amorim RF, Bezerra AC, Pombeiro GA, Guimarães LJ, Fregni F, Silva LP, da Mota LM. Salivary proteomics: a new adjuvant approach to the early diagnosis of familial juvenile systemic lupus erythematosus. Med Hypotheses. 2016;89:97-100. doi: 10.1016/j.mehy.2016.02.010

66. Ngounou Wetie AG, Wormwood KL, Russell S, Ryan JP, Darie CC, Woods AG. A pilot proteomic analysis of salivary biomarkers in autism spectrum disorder. Autism Res. 2015;8 (3):338-50. doi: 10.1002/aur.1450

67. Iavarone F, Melis M, Platania G, Cabras T, Manconi B, Petruzzelli R, Cordaro M, Siracusano A, Faa G, Messana I, Zanasi M,Castagnola M. Characterization of salivary proteins of schizophrenic and bipolar disorder patients by top-down proteomics. J Proteomics. 2014;103:15-22. doi: 10.1016/j.jprot. 2014.03.020

68. Ren R, Sun Y, Zhao X, Pu X. Recent advances in biomarkers for Parkinson's disease focusing on biochemicals. Clin Chem Lab Med. 2015;53(10):1495-506. doi: 10.1515/cclm-20140783

69. Xiao H, Wong DT. Method development for proteome stabilization in human saliva. Anal Chim Acta. 2012;722:63-9. doi: 10.1016/j.aca.2012.02.017
70. Ghafouri B, Tagesson C, Lindhal M. Mapping of proteins in human saliva using two-dimensional gel electrophoresis and peptide mass fingerprinting. Proteomics. 2003;3(6):1003-15. doi:10.1002/pmic.200300426

71. Vitorino R, Lobo MJ, Ferrer-Correira AJ, Dubin JR, Tomer KB, Domingues PM, Amado FM. Identification of human whole saliva protein components using proteomics. Proteomics. 2004;4(4):1109-15. doi: 10.1002/pmic.200300638

72. Grassl N, Kulak NA, Pichler G, Geyer PE, Jung J, Schubert S, Sinitcyn S, Cox J, Mann M. Ultra-deep and quantitative saliva proteome reveals dynamics of the oral microbiome. Genome Med. 2016;8:44. doi:10.1186/s13073-016-0293-0

73. Schipper R, Loof A, de Groot J, Harthoorn L, Dransfield E, van Heerde W. SELDI-TOF-MS of saliva: methodology and pretreatment effects. J Chromatogr B Analyt Technol Biomed Life Sci. 2007;15;847(1):45-53. doi: 10.1016/j.jchromb.2006.10.005

74. Ciavarella D, Mastrovincenzo M, D’Onofrio V, Chimenti C, Parziale V, Barbato E, Lo Muzio L. Saliva analysis by surfaceenhanced laser desorption/ionization time-of-flight mass spectrometry (SELDI-TOF-MS) in orthodontic treatment: first pilot study. Prog Orthod. 2011;12(2):126-131. doi: 10.1016/j. pio.2011.06.002

Sažetak

\title{
ULOGA NOVIH TEHNOLOGIJA U ODREĐIVANJU PROTEOMA SLINE NAKON POSTAVLJANJA FIKSNOG ORTODONTSKOG APARATA - RAZVOJ NOVIH DIJAGNOSTIČKIH ITERAPEUTSKIH PRISTUPA
}

\author{
V. Zgombic Popovic, L. Grgurević, V. Trkulja, R. Novak i D. Negovetić-Vranić
}

Ljudska slina obiluje proteinima raznolikih funkcija (enzimi, imunoglobulini, citokini) i podrijetla (krvna plazma, žlijezde slinovnice, mikroflora usne šupljine). Dinamika i volumen izlučene sline kao i njezin sastav (elektroliti, $\mathrm{pH}$, proteini) promjenjivi su tijekom dana, u različitim fiziološkim i patofiziološkim stanjima, lokalnim ali i sustavnim. Stoga se sastav sline, osobito proteinski, intenzivno istražuje u smislu identifikacije potencijalnih biljega i/ili mehanizama sustavnih i lokalnih bolesti. Nove tehnike analize proteina (tzv. proteomske tehnike) u biološkim tekućinama omogućile su velik napredak u stabilizaciji proteina sline (temeljni uvjet za njihovu analizu) te otkrivanje i onih koji se u slini nalaze u vrlo malim koncentracijama, uključujući i male proteine i peptide. $U$ ovom članku prikazana su temeljna svojstva suvremenih proteomskih tehnika poput tekućinske kromatografije povezane s masenom spektrometrijom (LC-MS), dvodimenzionalne elektroforezemasene spektrometrije (2-DE-MS) ili surface-enhaced laser desorption/ionization/time of flight/mass spectrometry (SELDITOF-MS). One omogućuju simultano traženje/identifikaciju stotina i tisuća proteinskih molekula i pružaju mogućnost identifikacije onih od potencijalne biološke važnosti u pojedinim stanjima. Ovaj pregled literature usredotočen je na dosadašnje znanje i mogućnosti koje proteomske tehnike pružaju u analizi učinaka ortodontskih aparata na proteinski sastav sline i potragu za potencijalnim biljezima (ne)uspješnosti liječenja ili izvršnim molekulama putem kojih ovaj terapijski postupak ostvaruje učinke.

Ključne riječi: Slina; Proteomika; Ortodontski aparat; Proteini sline 